\title{
State Protection to Human Right Because of Crime
}

\author{
Muhammad Helmi ${ }^{1}$, Nyoman Serikat Putra Jaya ${ }^{2}$, RB. Sularto ${ }^{3}$ \\ \{mhelmi354@yahoo.co.id. ${ }^{1}$, putrajaya1948@yahoo.co.id ${ }^{2}$, sularto@live.undip.ac.id ${ }^{3}$ \} \\ Student of Doctoral Program In Law Science, Diponegoro University, Semarang, Indonesia \\ ${ }^{1,}$ Diponegoro University, Semarang, Indonesia ${ }^{2,3}$
}

\begin{abstract}
A State is a group of people who live in a particular territory and organization under legitimate government whose sovereignty. State protection grant the people's rights depend on the state sovereignty. Sovereignty will depend on state needs. When the state gives justice to people, that give their rights, named human rights. Thus the state must increase protection of human rights over the crime committed by a person. Crime may cause a material and nonmaterial injury. However, the state sovereignty influences the form of state protection. Historically, according to Thomas Hobbes, state protection by the king is an obligation to his people neither felon nor misdemeanor. The people can't sue to the Royal Court, it is not his right, but the king's kindness The preamble of Constitution of the Republic of Indonesia at the fourth paragraph mention "...... in order to form a Government of the State of Indonesia that shall protect the whole people of Indonesia and the entire homeland of Indonesia, and in order to advance general prosperity, to develop the nation's intellectual life, and then .......". Then based on these provisions the government has an obligation to protect its people. Recently Indonesian must make a regulation to protect its people from the crimes. Now, sue for crime in Indonesia is represented by a prosecutor, but the prosecutor does not involve the victim.
\end{abstract}

Keywords: State Protection, Human Right, Crime.

\section{Introduction}

\section{Background}

Based on history, the man always lived together in a group of people (zoon political) from a long time ago. In the group of people, they struggle together to findfood, protect himself from danger, disasterand pursue his life. They interact insocial relations. So their life depends ona particular place as a source of viability, there must someoneof people or a group of people to regulate and lead his group. The leader has power from people and every one of people must be faithful to his rule.

A state is an agency to fulfill people desire. The more social interaction, so the more of needs. The state role to protectpeople's right to human rights. The aim of an applying to human rights on based approach is happiness all of human being.

${ }^{1}$ C.S.T. Kansil, Ilmu Negara Umumdan Indonesia (Jakarta :PTPradnyaParamita, 2001), hlm. 133 
Therefore right is a normative element embedded in every human being as a guidance behavior, protect of right, and ensure of dignity. Thus, the state makes a regulation on forbidden behavior. ${ }^{2}$

The increasing social interaction is unavoidable, will increase crime. Because people's needs increasing and the character of each person is different, being an individualist and disregard needs of others. The state role must be a protector of people right on mental and physical injury for a crime.

The injury person of a crimenamedthe victim. How state must protect the victim because ignored victim. The crime is undesired by the victim, but crime can happen to whoever. The state must pay attention to injuredthe victim. The state must prioritize regulation asa punishment for the crime perpetrator.

According to ArifGosita, Victim is they who suffer injury physically and spiritually because of other people action for individual or other interest which violate victim interest and human right. This definition is extended by ArifGosita, not only to the person but to the other legal entity are a legal body, a group of people, and corporation. The victim has tight relation to crime. ${ }^{3}$

An action is considered as a crime or not, so the state stipulate of action is a crime or a group of people consider of action is a crime. So the government is granted authority to make a charge and punishment to crime perpetrator, the crime perpetrator's right is reduced because that action violates the regulation. The government must have authority to exercise his power.

The different type or form of government distinguished according to the state sovereignty, so the protection state to person according to the sovereignty. The sovereignty may confine the government on the hands of one single magistrate or a particular people or the whole people. The three form of government may give protection to person because the state found for protecting the people.

Based on history, while the state is found, the group of people made an agreement to regulate their liberty. This agreement is named as Social Contract. Social Contract Theory is a liberal thought in The Enlightenment Era. They are three people who told about Social Contract Theory, namely Thomas Hobbes, John Locke, and Jean Jacques Rousseau. Each of man has different life background, so a result of though is different.

The preamble of Constitution of the Republic of Indonesia at the fourth Paragraph mention "Pursuant to which, in order to form a Government of the State of Indonesia that shall protect the whole people of Indonesia and the entire homeland of Indonesia, and in order to advance general prosperity, to develop the nation's intellectual life, and to contribute to the implementation of a world order based on freedom, lasting peace and social justice, Indonesia's National Independence shall be laid down in a Constitution of the State of Indonesia, which is to be established as the State of the Republic of Indonesia with sovereignty of the people and based on the belief in the One and Only God, on just and civilized humanity, on the unity of Indonesia and on democratic rule that is guided by the strength of wisdom resulting from deliberation / representation, so as to realize social justice for all the people of Indonesia".

2 James W. Nickel, HakAsasiManusia :RefleksiFilosofisAtasDeklarasi Universal HakAsasiManusia, (GramediaPustakaUtama, Jakarta, 1996), hal 24.

${ }^{3}$ M. Ali Zaidan, BahankuliahViktimologiFakultasHukumUniversitas Pembangunan Nasional, Jakarta Selatan, 2008, hal 46 
The fourth Paragraph mentioned to form a Government of the State of Indonesia that shall protect the whole people of Indonesia and the entire homeland of Indonesia, and in order to advance general prosperity, to develop the nation's intellectual life. The regulation confirms that the foundation of Indonesian government in exercising its authority to protect individuals and the whole nation of the Indonesia.

Analyzing on the shifting of thought on law development through the understanding ofthought historical development that emerged in a certain era is very important. ${ }^{4}$ Thus, analyzing the problem must consider characteristic of Indonesia. Because it is defined by space and time is different which form the rule of law.

State duty priorityfinds a solution to the human right problem. It is protected by the state. The state protection to the human right is the authority whichto act as a legitimate government in a particular territory. People desire is happiness and protection by the state.

Based on the description above, so the problem in this study is how state protection to human right because of crime?

\section{Analysis}

Based on history, persons sue to the royal court but are not their rights, however, it is kindness by kingdom authority. The person sues a case must demanding to royal officials name chancellor. 5

The Sovereign act which is necessary for the defense of state interest, this is the aim. To obtaining this aim, so the sovereign make an agreement with the people together. Thus he hasduty and authority.

For all human being, their right is the central achievement, however, it is duty by the state.State dutyto actis authority under a legitimate government. The sovereignty has tight relation to contract social. They told about contract social theory. They are Thomas Hobbes, John Locke, and Jean Jacques Rousseau.The sovereignty is not a static concept. The conditions evolved continuously parallel with social growth which found in contract social.

According to Thomas Hobbes about the social contract as cited in F.M. Suseno's book, the social contract is not contractionamong individuals with their state (the state is not founding yet, while they make a contract), however among individuals their self. The contract will form the state, so it is individuals right is handed in wholly to the state. After the state has power however it has not an obligation to people.

Thus, the absolute power of nature to govern men's actions, Hobbes now opposes an absolute freedom of action, regardless of the conditions which disposed the individual to act. It is this opposition which lurks behind the contradiction as to whether the sovereign has or has not the right to punish granted to him by his subjects. ${ }^{6}$

But Hobbes goes further than this. He also states that the individual does give the Sovereign the right to punish and that no subject may protest against any punishment meted

\footnotetext{
${ }^{4}$ AdjiSamekto, PergeseranPemikiranHukumdari Era YunaniMenujuPostmeodernisme, Jakarta :Konstitusi Press, 2015, hlm. 200

${ }^{5}$ SatjiptoRahadjo, IlmuHukum, cet. VII, PT Citra AdityaBakti : Bandung, 2012, hlm 258

${ }^{6}$ Alan Norrie, Thomas Hobbes And The Philosophy of Punishment, Law and Philosophy, Faculty of Law University of Dundee : Scotland, Volume 3 issue 2 1984, P.306
} 
out to him by the Sovereign because [since] every Subject is by this Institution Author of all the Actions, and a decision of the Sovereign Instituted. ${ }^{7}$

Where laws rule, the young Hobbes suggests, the skillful prince is unnecessary. Where no laws rule, "such confusion would follow in government, that the differences of Right and wrong, Just and unlawful, could never be distinguished." Conversation and commerce would be overthrown, all right would be perverted by power, and all honesty swayed by greatness. $^{8}$

Thus, according to Thomas Hobbes, the authority of protection has not state obligations, the form of state protection make a regulation of punishment. The victim has not right to sue, except kindness by kingdom authority.

Franklin saidLocke, search a conceptual understanding of sovereignty in a mixed constitution convincing.To make this point is not to undervalue Two Treatises as a politicaldocument suitable for the events unfolding around Locke in the 1680s. What Franklin's thesis about Locke's quest for consistency shows is theway in which Locke's thinking was driven by the rational motive forconsistency. There is at least one other example of this motive in TwoTreatises: Locke's analysis of the property. The question there was:How is it possible if all was given to man in common, for privateproperty to emerge? The doctrine of property plays an important rolein Locke's social philosophy, but he had to satisfy himself on the conceptual move from common to private first. ${ }^{9}$

Eduardo A. Velasquez, Washington and Lee University John Locke's vision of the prepolitical and political condition of human beings, of the inherent powers by which socalled individuals appropriate and master the gifts of nature through labor, and of the use of those powers to create governments for the protection of their persons and property stands at the fountainhead of liberal political philosophy. This vision is no mere abstraction. Locke's doctrine of right whichchief among them the right to the fruits of our labors. ${ }^{10}$

Numerous critiques and limitations have emerged. Hargrove ascribes Locke's strong endorsement of private property rights in part to his attempt to justify transferring ultimate rights to property from the monarchy to individual owners. ${ }^{11}$

Explanation of John Locke and Thomas Hobbes about contract social is different. According to John Locke, the people's right isnot handed in wholly to the king, therefore their rights must be protected. So Kingdom authority and people must regulate in the contract social. Therefore, if in the contract social has regulation as an instruction to the state which gives a protection to aperson, so they get it. This depends on the agreement.

\footnotetext{
${ }^{7}$ Alan Norrie, Thomas Hobbes And The Philosophy of Punishment, Law and Philosophy, Faculty of Law University of Dundee : Scotland, Volume 3 issue 2 1984, p. 304

${ }^{8}$ YishaiyaAbosch, The Conscientious Sovereign: Public and Private Rule in Thomas Hobbes's Early Discourses, California State University : American Journal of Political Science, Volume 50 issue 3 2006, pp. 625

${ }^{9}$ John W. Yolton, John Locke and the Theory of Sovereignty: Mixed Monarchy and the Right of Resistance in the Political Thought of the English Revolution by Julian H. Franklin, Sage Publications, Inc : Political Theory, Vol. 9, No. 2 (May, 1981), hlm. 268

${ }^{10}$ Eduardo A. Velasquez, John Locke and the Origins of Private Property: Philosophical Explorations of Individualism, Community, and Equalityby Matthew H. Kramer, Washington and Lee University Vol. 92 Issue 3 Tahun 1998, p. 685

${ }^{11}$ Brent M. Haddad, Property Rights, Ecosystem Management, And John Locke's Labor Theory Of Ownership, University of California volume 46 Issue 1 Tahun 2003, p. 24
} 
One of two key elements in Locke's treatment of rights distinguishes it from Grotius's natural law position.For Locke, construct of an "individual rights" whichbe understand as "sanction to restrict behavior of another". 12

Rousseau borrows from Hobbes the argument that sovereignty is an absolute power; it cannot be divided and remain sovereign; and it cannot be subject to 'fundamental laws' and remain sovereign. At the same time Rousseau takes from Locke and the jurisconsult have the idea that sovereignty is limited. Sovereignty is absolute, but not unlimited. The limits are those imposed by natural law and by the considerations of a public good. Sovereignty does not pass the bounds of public advantage. As an example of what Rousseau means by a natural law limitation, we may note his argument in the social contract that no agreement to enter into slavery could be a valid one because any agreement which wholly to the advantage of one party and wholly to the disadvantage of the other is void in natural law. ${ }^{13}$

In a way, Rousseau's response to the challenge of Hobbes is wonderfully simple. Clearly, men can be at the same time ruled and free if they ruled themselves. For them the obligation to obey will combine with the desire to obey; everyone in obeying the law will be acting only obedience to his own will. In saying this, Rousseau was going a good deal further than liberal theorists such as John Locke, who associated freedom with the people's consent to obey a constitutional monarchy in whom they invested sovereignty. For Rousseau there is no investment or transfer of sovereignty: sovereignty not only originates in the people, it stays there. ${ }^{14}$

On the whole, however, Rousseau, Law, and the sovereignty of the people stand as an important contribution to both Rousseau studies and democratic theory. It correctly insists that Rousseau's political theory, while at times abstract, is often remarkably practical and relevant to those who seek to find ways of broadening democratic participation in lawmaking and governance. ${ }^{15}$

The sovereign and the government. The Sovereign, according to Rousseau, is a general will or the community as a whole. The government is that group of individuals who rule the society. The government, not the Sovereign, confronts the issues of ruling a society, formulates the policies, and sets out the regulations for the society. ${ }^{16}$

Every people should have avote upon the question when it is finally put in its general form to the Sovereign; the debating, stating of views, and the making of proposals belongs to the members of the government, not of the Sovereign. ${ }^{17}$

So based on explanation, every violation of a law is considered as rebellion. The crime perpetrator violate the agreement by his act: his rights are reduced of himas an immoral person and can be exiled or put to death.

A study of state protection institutions and practices reveals about the way that state actors choose of state sovereignty. This choice influence form of protection. The Main

${ }^{12}$ B. Andrew Lustig, Natural Law, Property, and Justice: The General Justification of Property in John Locke, The Journal of Religious Ethics, Vol. 19, No. 1 (Spring, 1991), pp. 130

${ }^{13}$ Jean Jacques Rousseau, The Contract Social, Penguin Group : England, 1986, p. 38

${ }^{14}$ Maurice Cransto, Jean-Jacques Rousseau And The Fusion Of Democratic Sovereignty With Aristocratic Government, History European Ideas, Vol 11. 1989, pp 420-421

${ }^{15}$ Ethan Putterman, Rousseau, Law, and the Sovereignty of the People, The Journal of Politics, Vol. 74, No. 1, January 2012, pp.2

${ }^{16}$ Frank Marini, Popular Sovereignty but Representative Government: The Other Rousseau, Midwest Journal of Political Science, Vol. 11, No. 4 (Nov., 1967) . pp. 457

${ }^{17}$ Frank Marini, Popular Sovereignty but Representative Government: The Other Rousseau, Midwest Journal of Political Science, Vol. 11, No. 4 (Nov., 1967) pp. 465 
principleof people to obtainright and happiness. Therefore those people who make contract together to form the Commonwealth must be bound by the decision of the majority as to the selection of the Sovereign. so the people give to a power ofthe sovereign.

The example, theory of sovereignty delivered by Thomas Hobbes. The state has authority in making regulation on punishment and protection to victims who are injured. The state must consider condition or ask the victim. Is there a right of intervention? How and when should it be exercised? The state has power, so that can do it. This intervention depends on the agreement in the social contract.

The form of sovereignty, which ultimately influenceon the form of protection. In situations is not according, so sovereignty creates a conducivecondition to a human being. This depends on how state exercises its sovereignty.

The modern states choose a form of sovereignty which is compatible with development. Thus unswerving allegiance to the Sovereign, the selection of 'true' ideas and the suppression of 'false' ideas, because this is the agency of control. So can be stipulate "the behavior of people of error, mistake or negligence. When discusses the particular details of what should duty as part of the Sovereign's duty. Such things as to respect rights of others and not to injure others.

Forexample is the form sovereignty of the people will make the new norm of the responsibility to protect. This hand in those concepts of sovereignty offers an elegant, so potentially a new constructive.

The state has a duty to prosecute and make a decision to crime perpetrator. The people must believe in a verdict by state. How is protection state to a victim who got an injury? How is the state say to justice but not involving the victim?. In Indonesia protection state to a human being is regulated by Constitution of Indonesia.

The Constitution of the Republic of Indonesia offers an apparently compelling solution to this study: the state should view the relationship between sovereignty and intervention as complementary rather than contradictory. The idea of reshaping of sovereignty more closely to the responsibility of states to their citizens. Therefore, sovereignty is no longer conceived as undisputed control over territory, but rather as a conditional right, upon respect for a minimum standard of human rights to a victim.

According to the preamble of Constitution of the Republic of Indonesia at the fourth Paragraph mention "...... in order to form a Government of the State of Indonesia that shall protect the whole people of Indonesia and the entire homeland of Indonesia, and in order to advance general prosperity, to develop the nation's intellectual life, and then .......".

The regulation to form a Government of the State of Indonesia that must protect the whole people of Indonesia.The stateduty must give protection to people including the victim. Therefore the state must intervene to protect the victim. There must attention that is the primary purpose of the intervention must be to the victims concerned.

The Commission turned the idea of sovereignty on its head and stated that the primary responsibility of a state is to protect all its citizens. When a state is unwilling or unable to halt or avert serious harm to its population. ${ }^{18}$

The idea of protection depends on a concept of human right which secures people's right, respect for their dignity and worth as human beings. Protection of state is responsible, like which is related to state duty. Although this is the same as saying that states to intervene, it raises the question whether justice and law should be more closely aligned.

\footnotetext{
${ }^{18}$ Mary-Wynne Ashford, The responsibility to protect: A new notion of state sovereignty, Medicine, Conflict and Survival, Washington State University Libraries, volume 19 issue 1 thn 2003, p. 36
} 
Although the crime perpetrator committed acrime, so he has rights. The same also the victim has rights which are injured by an act of crime. What basis which precede the responsibility to protect interesting of crime perpetrator, rather than the responsibility to victim right. Understanding the issue by noticing, whatever the executive action, its authority must come from the sovereignty which is further regulated by laws.

The state sovereignty has a responsibility to protect its citizens from avoidable catastrophe. When a victim is unable to do, that responsibility must be taken over by the state.Several reasons why its formulation must be taken over by the state because it has power. On the victims suffering who seek assistance, on the claims, so state has rights intervening.

Based on above regulation, Whose sovereignty it is? sovereignty in the hand of people, but the sovereignty is executed according to the laws. Thus only the laws bring the right to direct authority. This is regulated by Constitution of Indonesia Chapter I Form of the State and Sovereignty Article 1 section 2 Sovereignty is in the hands of the people and implemented according to this Constitution.Then Article 4 section 1 The President of the Republic of Indonesia shall hold the power of government in accordance with the Constitution.

The regulation as Rousseau said the people invested sovereignty to a constitutional monarch. Sovereignty is not executed by people, but it stays there. However, the regulation said sovereignty is implemented according to this Constitution.

The entire framework to know state purpose rests on the idea of sovereignty. The sovereignty of people gives themfreedom of speech, freedom of association, and freedom to get happiness. However, they lose their right because of a result of their action. On based Article 28J(2) In exercising his/her rights and freedoms, every person shall have the duty toaccept the restrictions established by law for the sole purposes to guaranteethe recognition and respect of the rights and freedoms of others and of satisfyingjust demands based upon considerations of morality, religious values, securityand public order in a democratic society.

The regulation such as Locke said, the concept of an "individual right"to protection, so can regulate sanction to restrict the behavior of another.This as a form of protection by the state.

So the concept of people sovereignty is not only political but also moral and the protector. The protection can be conceived as a norm imposed is not only to citizens but also the individual. "Each individual, as a part of citizens, can have a particular will which must is protected.

Therefore the government act on sovereignty must protect people, particularly injured people. This regulation is Article 28G (1) Every person shall have the right to protection of his/herself, family, honor, dignity, and property, and shall have the right to feel secure against and receive protection from the threat of fear to do or not do something that is a human right. (2) Every person shall have the right to be free from torture or inhumane and degrading treatment and shall have the right to obtain political asylum from another country.

Based on the regulation, the state hasthe capacity to assume the responsibility. This becomes problematic when the responsibility of state must involve the victim. IfState protection to a victim is put victim's interest as part of state obligation. So the state involves victim to sue his injury. This is a human right which to be the expectation of people. 
Analysis of regulation, the obligation to act on behalf of a state. The state has the power to intervene. The power must take the necessary and proper measures in order to restore and ensure public order and life.

The protection of a victim that can avoid the conundrum surrounding right of intervention.This obligation of responsibility and protection. It rests on a constitution of Indonesia and its regulation. State intervention to act term process of rebuilding. The recommended priorities are to respect the dignity and basic rights all people within the state.

Van Boven, a special pioneer of United Nations, explains that right of victims of a crime comprehensively, that is not only right to know and right to justice but also right to reparation. The human right is regulated merge in various regulatory instruments, and include explicitly in jurisprudence by the judiciary. ${ }^{19}$

Compensation is an obligation in cash or another form, like health care, give a job, house, education, and land. While restitution is an obligation to return of property or payment of injury, or loss of injury by the crime. And rehabilitation is an obligation to heal the victims medically and socially. ${ }^{20}$

If peace and justice are to be obtained and maintained, it must be well governed. Thus the state has duty and power not only to decide on punishment the crime perpetrator but also protect victim's right.

\section{Conclusion}

State protection grant the people rights depend on state sovereignty. Sovereignty will dependon state needs. Based on history, sovereignty of kingdom make an absolute. Everything must following to the king desire. Like, persons sue to the royal court but are not their right, however, it is kindness by kingdom authority. The person sues a case must demanding to royal officials name chancellor. Analyzing on thought on law development through the understanding of thought historical development that emerged in a certain era is very important. Thus, analyzing the problem must consider characteristic of Indonesia. This is influance by space and time is different which form the sovereignty. Based on the regulation Sovereignty is in the hands of the people and implemented according to this Constitution. The President of the Republic of Indonesia shall hold the power of government in accordance with the Constitution. In exercising their right and freedom, every person shall have the duty to accept the restrictions established by law and next. The regulation confirms that the foundation of Indonesian of government in exercising its authority to protect individuals and the whole nation of Indonesia. So protection of state is responsible. The protection to people is an obligation to responsible and protection by the state. It rests on the constitution of Indonesia and its regulation. The recommended priorities are to respect the dignity and basic rights all of the people within the state including the victim. Now, crime sue in Indonesia is represented by a prosecutor, but the prosecutor does not involves the victim. Although based on regulation provisions the state has an obligation to protect its people.The state has duty and power not only to decide punishment to crime perpetrator but also protect victim's right. If state protection to a

${ }^{19}$ Theo Van Boven, Mereka Yang MenjadiKorban: HakKorbanAtasRestitusi, Kompensasi, Dan Rehabilitasi, (Jakarta : ELSAM, 2002), hlm xvi.

${ }^{20}$ Ibid, hlm xvii. 
victim can be done through putting the victim's interest as part of state obligation. So the state involves victim to sue his injury. This is a human right as expected by people.

\section{References}

[1]. ${ }^{1}$ C.S.T. Kansil, Ilmu Negara Umumdan Indonesia (Jakarta :PTPradnyaParamita, 2001), hlm. 133

[2]. 'James W. Nickel, HakAsasiManusia :RefleksiFilosofisAtasDeklarasi Universal HakAsasiManusia, (GramediaPustakaUtama, Jakarta, 1996), hal 24.

[3]. ${ }^{1}$ M. Ali Zaidan, BahankuliahViktimologiFakultasHukumUniversitas Pembangunan Nasional, Jakarta Selatan, 2008, hal 46

[4]. ${ }^{1}$ AdjiSamekto, PergeseranPemikiranHukumdari Era YunaniMenujuPostmeodernisme, Jakarta :Konstitusi Press, 2015, hlm. 200

[5]. ${ }^{1}$ SatjiptoRahadjo, IlmuHukum, cet. VII, PT Citra AdityaBakti : Bandung, 2012, hlm 258

[6]. ${ }^{1}$ Alan Norrie, Thomas Hobbes And The Philosophy of Punishment, Law and Philosophy, Faculty of Law University of Dundee : Scotland, Volume 3 issue 2 1984, P.306

[7]. ${ }^{1}$ Alan Norrie, Thomas Hobbes And The Philosophy of Punishment, Law and Philosophy, Faculty of Law University of Dundee : Scotland, Volume 3 issue 2 1984, p. 304

[8]. 'YishaiyaAbosch, The Conscientious Sovereign: Public and Private Rule in Thomas Hobbes's Early Discourses, California State University : American Journal of Political Science, Volume 50 issue 32006 , pp. 625

[9]. ${ }^{1}$ John W. Yolton, John Locke and the Theory of Sovereignty: Mixed Monarchy and the Right of Resistance in the Political Thought of the English Revolution by Julian H. Franklin, Sage Publications, Inc : Political Theory, Vol. 9, No. 2 (May, 1981), hlm. 268

[10]. ${ }^{1}$ Eduardo A. Velasquez, John Locke and the Origins of Private Property: Philosophical Explorations of Individualism, Community, and Equality by Matthew H. Kramer, Washington and Lee University Vol. 92 Issue 3 Tahun 1998, p. 685

[11]. ${ }^{1}$ Brent M. Haddad, Property Rights, Ecosystem Management, And John Locke's Labor Theory Of Ownership, University of California volume 46 Issue 1 Tahun 2003, p. 24

[12]. ${ }^{1}$ B. Andrew Lustig, Natural Law, Property, and Justice: The General Justification of Property in John Locke, The Journal of Religious Ethics, Vol. 19, No. 1 (Spring, 1991), pp. 130

[13]. ${ }^{1}$ Jean Jacques Rousseau, The Contract Social, Penguin Group : England, 1986, p. 38

[14]. ${ }^{1}$ Maurice Cransto, Jean-Jacques Rousseau And The Fusion Of Democratic Sovereignty With Aristocratic Government, History European Ideas, Vol 11. 1989, pp 420-421

[15]. ${ }^{1}$ Ethan Putterman, Rousseau, Law, and the Sovereignty of the People, The Journal of Politics, Vol. 74, No. 1, January 2012, pp.2

[16]. ' ${ }^{1}$ Frank Marini, Popular Sovereignty but Representative Government: The Other Rousseau, Midwest Journal of Political Science, Vol. 11, No. 4 (Nov., 1967) . pp. 457

[17]. ${ }^{1}$ Frank Marini, Popular Sovereignty but Representative Government: The Other Rousseau, Midwest Journal of Political Science, Vol. 11, No. 4 (Nov., 1967) pp. 465

[18]. 'Mary-Wynne Ashford, The responsibility to protect: A new notion of state sovereignty, Medicine, Conflict and Survival, Washington State University Libraries, volume 19 issue 1 thn 2003, p. 36

[19]. ${ }^{1}$ Theo Van Boven, Mereka Yang MenjadiKorban: HakKorbanAtasRestitusi, Kompensasi, Dan Rehabilitasi, (Jakarta : ELSAM, 2002). 